\title{
Randomized comparison of the effectiveness of nasal intubation using a GlideScope video laryngoscope with Magill forceps versus vascular forceps in patients with a normal airway Étude randomisée comparant l'efficacité de l'intubation nasale avec un vidéolaryngoscope et une pince Magill versus une pince vasculaire chez des patients ayant des voies aériennes normales
}

\author{
Jong H. Yeom, MD, PhD • Mi K. Oh, MD • Woo J. Shin, MD, PhD • Dae W. Ahn, MD • \\ Woo J. Jeon, MD, PhD $\cdot$ Sang Y. Cho, MD, PhD \\ Received: 22 March 2017/Revised: 3 August 2017/Accepted: 13 September 2017/Published online: 26 September 2017 \\ (C) The Author(s) 2017. This article is an open access publication
}

\begin{abstract}
Purpose The GlideScope ${ }^{\circledR}$ video laryngoscope $(G V L)$ is widely used for nasotracheal intubation in dental and facial plastic surgery. The angle of the Magill forceps is different from that of the GVL blade, which suggests that the Magill forceps are not the ideal forceps for use with the GVL. The purpose of this study was to compare the effectiveness of the Magill forceps vs vascular forceps for nasotracheal intubation using the GVL.

Methods This study included 60 patients scheduled to undergo elective surgery requiring nasotracheal intubation. Patients were assigned to one of two groups-i.e., Magill forceps (group M) or vascular forceps along with a tube exchanger (group V), by computer randomization. The primary outcome was total intubation time, defined as the time from when the anesthesiologist picked up the device to the time when three successive end-tidal $\mathrm{CO}_{2}$ waves were obtained following intubation. Secondary outcomes were blood in the endotracheal tube and trauma to the oral tissues or teeth. A blind observer assessed the presence of sore throat one hour and $24 \mathrm{hr}$ after surgery.

Results The total intubation time was significantly different between group $M$ and group $V(96.1 \mathrm{sec}$ and $78.1 \mathrm{sec}$, respectively; mean difference, 18 sec; $95 \%$ confidence
\end{abstract}

J. H. Yeom, MD, $\mathrm{PhD}$ - M. K. Oh, MD .

W. J. Shin, MD, PhD · D. W. Ahn, MD .

W. J. Jeon, MD, PhD - S. Y. Cho, MD, PhD (ه)

Department of Anesthesiology and Pain Medicine, Hanyang

University Guri Hospital, 249-1, Gyomun-dong, Guri-si,

Gyeonggi-do 471-701, Republic of Korea

e-mail: chosy@hanyang.ac.kr interval (CI), 13.7 to 49.7). The incidence of epistaxis in group $M$ was significantly greater than that in group V $(46.7 \%$ vs $16.7 \%$, respectively; relative risk, 2.8; 95\% CI, 1.2 to 6.8). Conclusion The total intubation time was significantly less with the vascular forceps (and tube exchanger) than with the Magill forceps. Using vascular forceps also reduced the incidence of epistaxis compared with that using the Magill forceps. Using a tube exchanger and vascular forceps offers advantages over use of Magill forceps when a GlideScope video laryngoscope is used for nasotracheal intubation.

Trial registration: http://www.who.int/ictrp/network/cris2/ en/, CRIS, KCT0001310. Registered 29 July 2014.

\footnotetext{
Résumé

Objectif Le vidéolaryngoscope Glidescope ${ }^{\circledR}$ (VLG) est couramment utilisé pour l'intubation naso-trachéale en chirurgie plastique dentaire et faciale. L'angle de la pince Magill est différent de celui de la lame du VLG, ce qui suppose que l'utilisation de cette pince n'est pas idéale avec le VLG. L'objectif de cette étude est de comparer l'efficacité de la pince Magill et celle de la pince vasculaire pour une intubation naso-trachéale au moyen d'un VLG.

Méthodes Cette étude a inclus 60 patients devant subir une chirurgie planifiée nécessitant une intubation nasotrachéale. Les patients ont été répartis de manière aléatoire par ordinateur en deux groupes : le groupe où une pince Magill a été utilisée (groupe M) et celui avec une pince vasculaire avec échangeur de tube (groupe V). Le critère d'évaluation principal était le temps total d'intubation défini comme étant le temps écoulé entre le moment où l'anesthésiologiste a pris le matériel d'intubation jusqu'au moment où 3 courbes successives
} 
de $\mathrm{CO}_{2}$ ont été obtenues après l'intubation. Les critères d'évaluation secondaires étaient la présence de sang dans le tube endotrachéal et un traumatisme des tissus buccaux ou des dents. Un observateur tenu à l'aveugle a évalué la présence d'un mal de gorge 1 h et 24 h après la chirurgie. Résultats Le temps total d'intubation était significativement différent entre les groupes $M$ et $V$ : respectivement, 96,1 s et 78,1 s; différence moyenne, $18 \mathrm{~s}$; intervalle de confiance [IC] à $95 \%$ : $-13,7$ à $-49,7$. L'incidence de l'épistaxis a été significativement plus importante dans le groupe $M$ que dans le groupe $V$ : respectivement $46,7 \%$ contre $16,7 \%$; risque relatif, 2,8 ; IC à $95 \%: 1,2$ à 6,8 .

Conclusion Le temps total d'intubation a été significativement plus court avec la pince vasculaire (et l'échangeur de tube) qu'avec la pince Magill. L'utilisation de la pince vasculaire a également réduit l'incidence des épistaxis par rapport à l'utilisation de la pince Magill. L'utilisation d'un échangeur de tube et d'une pince vasculaire présente des avantages par rapport à l'utilisation d'une pince Magill avec un vidéolaryngoscope GlideScope pour l'intubation naso-trachéale.

Enregistrement de l'étude: http://www.who.int/ictrp/ network/cris2/en/, CRIS, KCT0001310. Enregistré le 29 juillet 2014.

The GlideScope ${ }^{\circledR}$ video laryngoscope (GVL) (Verathon Medical Inc., Bothell, WA, USA) is widely used for nasotracheal intubation in dental and facial plastic surgery. ${ }^{1}$ Magill forceps are often used when performing nasotracheal intubation with direct laryngoscopy, but the angle of these forceps is different from that of the GVL blade, which can complicate the procedure. In contrast, vascular forceps have an angulation similar to that of the GVL blade (Fig. 1). ${ }^{2}$

There are reports of conversion from oral to nasal intubation using endotracheal tube exchangers ${ }^{3,4}$; however, it remains unclear if tube exchangers facilitate nasotracheal intubation.

The purpose of this study was to compare the effectiveness of using the GVL with Magill forceps (group M) $v s$ with vascular forceps in conjunction with a tube exchanger (group V) for nasotracheal intubation. We hypothesized that total intubation time would be significantly shorter in group $\mathrm{V}$ than in group $\mathrm{M}$. In addition, we expected a lower incidence of epistaxis in group $\mathrm{V}$ than in group $\mathrm{M}$.

\section{Methods}

This study was approved by the Hanyang University Guri Hospital Institutional Review Board on Human Subjects
Research and Ethics Committees (GURI 2014-16). All patients provided written informed consent prior to enrolment. Sixty patients (aged 18-65 years) scheduled for elective surgery and classified as American Society of Anesthesiologists physical status I or II were included in the study. Exclusion criteria were patients with a history of difficult intubation, larynx surgery, or larynx radiotherapy; anticipated esophago-tracheal reflux; Mallampati view 3 or 4; frequent episodes of epistaxis; or bleeding tendency. On preoperative visits, residents evaluated the patients for the presence of nasal injury, dyspnea, sinusitis, allergic rhinitis, and a history of smoking.

Upon the patient's arrival at the operating room, a nurse, who was blinded to the study, opened an envelope containing the randomization numbers and group information-i.e., Magill forceps (M) or vascular forceps (V). The following patient characteristics were measured and recorded: age, sex, weight, height, body mass index, Mallampati view, thyromental distance, maximal mouth opening, and neck circumference. Elective monitoring was performed. A bispectral index (BIS) monitor (A-2000TM, version 3.3; Aspect Medical System Inc., Newton, MA, USA) was used to monitor the depth of anesthesia.

Before induction of anesthesia, one side of the patient's nostril was blocked. The patient was then instructed to sneeze through the opposite nostril to confirm that the nostril was blocked, and the selected nostril was packed with gauze containing epinephrine. Denitrogenation was performed by having the patients breathe $100 \%$ oxygen for three minutes to remove all nitrogen gas from their airway. After acquiring intravenous access and completing denitrogenation, remifentanil and $2 \%$ propofol were administered by an Orchestra $^{\circledR}$ Base Primea infusion device (Fresenius Kabi, France). Rocuronium 0.6 $\mathrm{mg} \mathrm{kg}^{-1} i v$ was administered when the BIS value was $<$ 60 and verbal response was absent. An Innervator nerve stimulator (Fisher \& Paykel Healthcare, Auckland, New Zealand) was placed along the ulnar nerve to monitor the train-of-four reactions, and nasotracheal intubation was initiated once the train-of-four reaction was zero.

Nasotracheal tubes (NTTs) (Mallinckrodt Medical, Covidien, Ireland) with an internal diameter of 7.0 and $6.5 \mathrm{~mm}$ were used for males and females, respectively. The tubes were placed into sterile saline maintained at $45^{\circ} \mathrm{C}$ and then lubricated with water-soluble gel. In group $\mathrm{M}$, the NTT was oriented with the concavity facing caudally, and the tube was advanced along the nasal floor to the posterior nasopharyngeal wall. The GlideScope blade was then placed into the patient's mouth, and the tip of the NTT was inserted into the trachea using Magill forceps via the GVL monitor (Fig. 1). In group $\mathrm{V}$, a lubricated Sheridan T.T.X. ${ }^{\mathrm{TM}}$ endotracheal tube exchanger (Teleflex Medical, Durham, NC, USA) was inserted into the NTT with the tip 


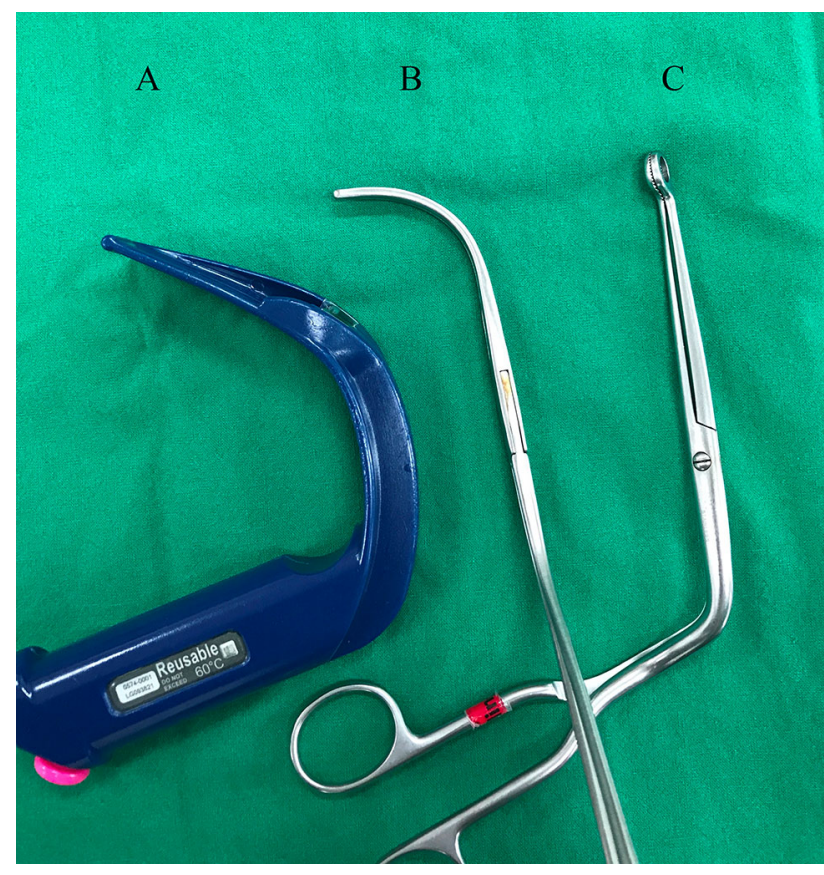

Fig. 1 Demonstration of different angles of a GlideScope blade (\#4), b Vascular forceps, and c Magill forceps

of the tube exchanger protruding approximately $15 \mathrm{~cm}$ from the distal end of the NTT (Fig. 2). A tube exchanger lubricated with water-soluble gel was inserted into the nasal cavity, and the GlideScope blade was then placed into the patient's mouth. Using vascular forceps, the tube exchanger was advanced along the lower pathway of the nasal airway and passed through the glottis. The NTT was then advanced along the tube exchanger via the GVL monitor. Three anesthesiologists (M.K.O., W.J.J., and S.Y.C.) performed the nasotracheal intubations.

Total intubation time was defined as the time from when the anesthesiologist picked up the device to when three successive end-tidal $\mathrm{CO}_{2}$ waves were obtained following intubation. Immediately after extubation, the patient's airway was assessed for blood in the intubation tube, the presence of damaged oral tissue, damage to the teeth, and other complications. A blinded observer assessed the patients for sore throat at one and $24 \mathrm{hr}$ postoperatively.

To calculate the sample size, we used the average (standard deviation [SD]) intubation time obtained from a pilot studyi.e., 66.1 (15.5) sec. We needed 28.8 patients to detect a $20 \%$ difference between the groups. Assuming a $2 \%$ dropout rate, this study required 60 patients. We used $\operatorname{IBM}^{\circledR} \operatorname{SPSS}^{\circledR}$ Statistics 21.0 for Windows for statistical analyses (SPSS Inc., Chicago, IL, USA). Unpaired Student's $t$ tests were used to compare the numerical data of the two groups. The mean difference and the $95 \%$ confidence interval (CI) of the mean difference were calculated. Categorical data (ratio of sore throat, epistaxis) were analyzed using Fisher's exact test. The

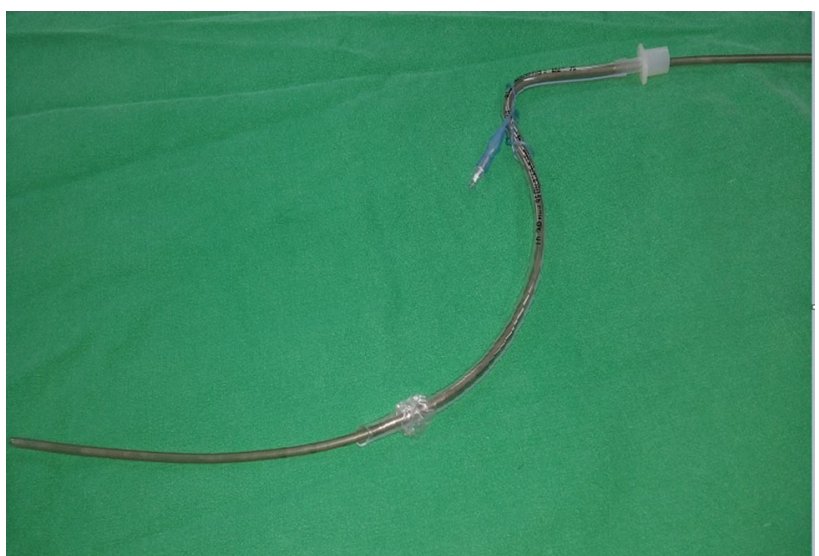

Fig. 2 Demonstration of tube exchanger positioning during the study (with approximately $15 \mathrm{~cm}$ of the exchanger protruding from the distal end of the nasotracheal tube)

relative risks of the proportion of categorical data and 95\% CI were calculated.

\section{Results}

Sixty patients were enrolled in our study from November 2014 to September 2015. No patients were excluded during the study (Fig. 3). There were no significant differences between the two groups with regard to demographic data (Table 1). Thyromental distance, neck circumference, and mouth opening were also similar between the groups (Table 1). There were no cases of hypoxemia or desaturation in either group during nasotracheal intubation. The glottic views obtained by GVL were not significantly different between the two groups (Table 2).

There was a significant difference in total intubation time between the two groups (group M, $96.1 \mathrm{sec} v s$ group $\mathrm{V}, 78.1 \mathrm{sec}$; mean difference, $18 \mathrm{sec} ; 95 \% \mathrm{CI}, 13.7$ to 49.7 ) (Table 2). There was a lower numerical incidence of sore throat in group $\mathrm{V}$ than in group $\mathrm{M}$, both in the recovery room ( $16.7 \%$ vs $6.7 \%$, respectively) and at 24 hours (16.7\% vs $3.3 \%$, respectively; relative risk, 2.5 at $24 \mathrm{hr}$ ), although the differences were not significant (Table 2).

There was a significantly lower incidence of epistaxis in group $\mathrm{V}$ than in group $\mathrm{M}(46.7 \%$ vs $16.7 \%$; relative risk, 2.8; 95\% CI, 1.2 to 6.8 ) (Table 2).

\section{Discussion}

In this study, we found that the total intubation time for nasal intubation was significantly shorter using the GVL and vascular forceps-guided tube exchanger than using the GVL with Magill forceps. The incidence of epistaxis was 


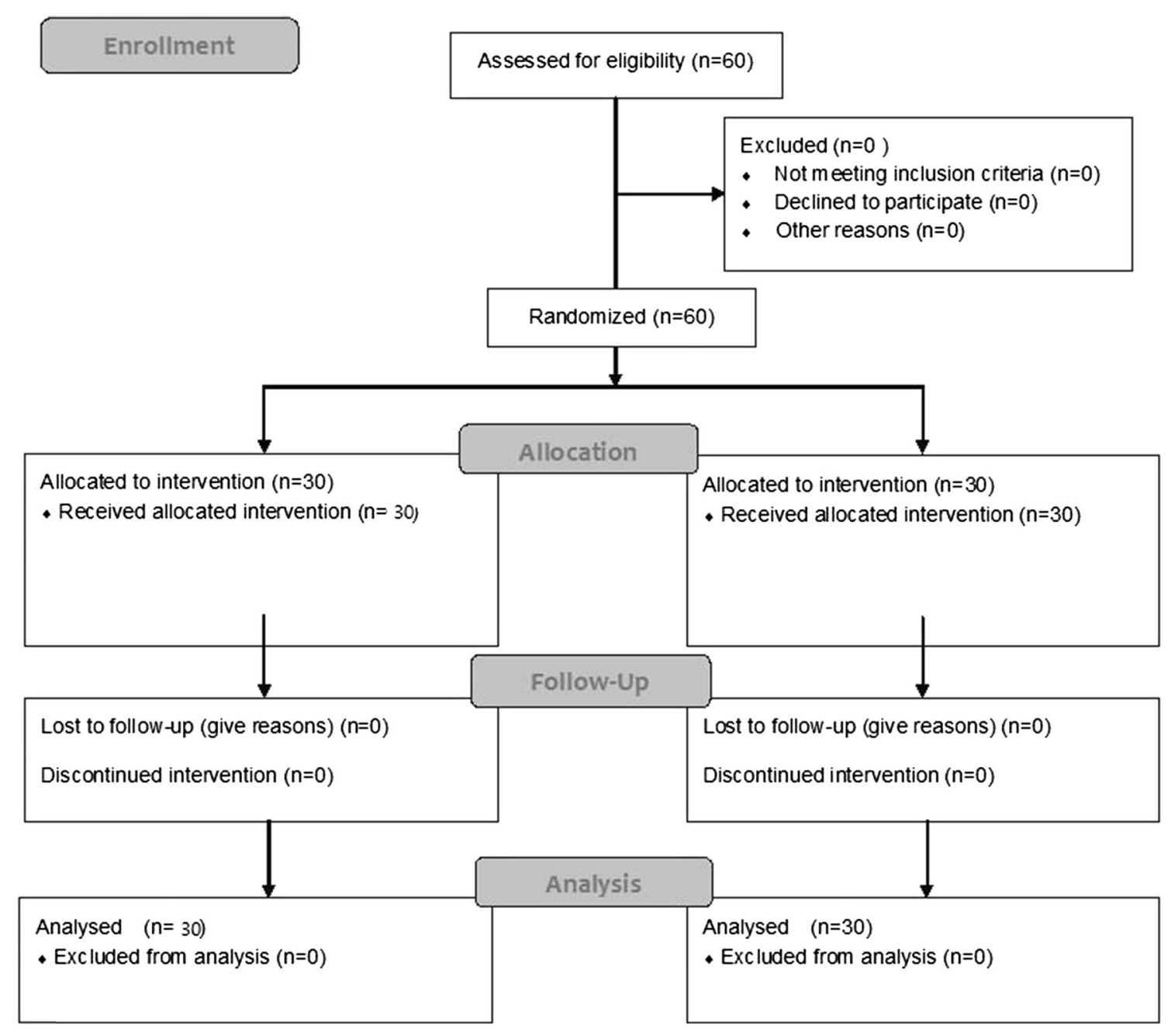

Fig. 3 Study flow diagram

significantly lower in the vascular forceps group. All nasal intubations were successfully completed.

Compared with the direct laryngoscope, the tip of the GVL was directed toward the vallecula. This enhanced the glottic view and eventually resulted in an increase in the success rate of endotracheal intubation in the difficult airway. ${ }^{5}$ In a difficult airway, such as in patients with a cervical collar or restricted cervical movement, the GVL acquired a good laryngeal view and shortened the time for endotracheal intubation. ${ }^{6}$ Nevertheless, despite a good glottic view, there were several cases of difficult intubation due to restricted neck movement. ${ }^{7}$ Several methods were investigated to overcome this difficulty. In routine use, the GVL has a $60^{\circ}$ angled stylet; however, use of a $90^{\circ}$ angled stylet resulted in easier endotracheal intubation. ${ }^{8}$ Prior studies using a fibreoptic scope with the GVL showed effective endotracheal intubation. ${ }^{9,10}$ In patients under general anesthesia, the fibreoptic endoscope is used as a controllable stylet. In contrast, in patients under conscious sedation, the fibreoptic bronchoscope enters the airway along the GVL blade according to adjustments of its positional camera. In other studies, ${ }^{2,11}$ the angle of the vascular forceps was similar to that of the GVL blade, and the tube exchanger served as a guide for introducing the endotracheal tube. Ultimately, endotracheal intubation was effective using the vascular forceps along with the tube exchanger.

Compared with the direct laryngoscope, the GVL facilitates routine nasotracheal intubation. ${ }^{1,12}$ There are many studies regarding facilitating nasotracheal intubation with additional tools or techniques. ${ }^{13-15}$ For instance, thermosoftening the nasotracheal tube can improve flexibility and navigability though the nasal pathway. Nasogastric tubes can pass through the lower pathway of the nasal cavity due to their flexibility and pliability. In a previous study from our group, ${ }^{2}$ we found that using a forceps-guided tube exchanger could be advantageous when using the GVL. In this study, the total intubation time in group $\mathrm{V}$ was significantly shorter than that in group M. This difference might be due to the flexibility and 
Table 1 Demographic data

\begin{tabular}{lll}
\hline & Group M $(n=30)$ & Group V $(n=30)$ \\
\hline Age $(\mathrm{yr})$ & $45.5(12.5)$ & $44.0(14.6)$ \\
Sex $(\mathrm{M} / \mathrm{F})$ & $15 / 15$ & $13 / 17$ \\
Height $(\mathrm{cm})$ & $165.7(8.6)$ & $166.3(9.0)$ \\
Weight $(\mathrm{kg})$ & $66.4(9.5)$ & $70.3(9.5)$ \\
Body mass index $\left(\mathrm{kg} \cdot \mathrm{m}^{-2}\right)$ & $24.2(2.7)$ & $25.3(2.7)$ \\
Thyromental distance $(\mathrm{cm})$ & $7.0(0.7)$ & $6.7(0.7)$ \\
Neck circumference $(\mathrm{cm})$ & $37.8(4.1)$ & $38.9(3.8)$ \\
Mouth opening $(\mathrm{cm})$ & $3.9(0.4)$ & $3.8(0.9)$ \\
\hline
\end{tabular}

Values are expressed as number or mean (SD)

Table 2 Characteristics of nasotracheal intubation and associated complications

\begin{tabular}{llll}
\hline & Magill forceps $(n=30)$ & $\begin{array}{l}\text { Vascular forceps with tube } \\
\text { exchanger }(n=30)\end{array}$ & $\begin{array}{l}\text { Difference in means or relative } \\
\text { risk (95\% CI) }\end{array}$ \\
\hline Glottic View (grades 1/2/3/4) & $19 / 10 / 1 / 0$ & $23 / 6 / 1 / 0$ & $18(13.7$ to 49.7$)$ \\
Total intubation time (sec) & $96.1(30.4)$ & $78.1(21.9)$ & \\
Intubation attempts (1/2/) & $23 / 7$ & $28 / 2$ & $2.5(0.5$ to 11.8$)$ \\
Sore throat in recovery room & $5 / 30(16.7 \%)$ & $2 / 30(6.7 \%)$ & $5.1(0.6$ to 40.3$)$ \\
Sore throat at 24 hr & $5 / 30(16.7 \%)$ & $1 / 30(3.3 \%)$ & $2.8(1.2$ to 6.8$)$ \\
Epistaxis (yes/no) & $14 / 16(46.7 \%)$ & $5 / 25(16.7 \%)$ & 0.01 \\
Dental injury & 0 & 0 & 0.15 \\
\hline
\end{tabular}

Values are expressed as number, proportion $(\%)$, or mean (standard deviation). Relative risks are calculated for categorical data. $\mathrm{CI}=$ confidence interval

pliability of a tube exchanger and the easy passage of the nasotracheal tube through the glottis using vascular forceps.

Many methods have been introduced to reduce the incidence of epistaxis. ${ }^{13-17}$ Thermosoftening the tube, as mentioned above, resulted in tube misplacement into the upper pathway in $73.3 \%$ of cases. ${ }^{15}$ This misplacement caused trauma to the middle turbinate and massive bleeding. Flexible nasogastric tube insertion can ensure that tubes pass into the lower pathway, reducing the bleeding. Another method is the use of the nasopharyngeal airway (Wendl tube) as a pathfinder, in which a soft and flexible airway is gently inserted into the nasopharynx along the floor of the nasal cavity. In our study, use of the conventional method in group $\mathrm{M}$ by tube warming with $45^{\circ} \mathrm{C}$ saline and Magill forceps resulted in more nasal bleeding than in group $\mathrm{V}$ with the tube exchanger and vascular forceps $(46.7 \%$ vs $16.7 \%$, respectively). This discrepancy might be due to the flexibility and pliability of the tube exchanger which allowed it to pass into the lower pathway.

Sore throat is a common complication of nasotracheal intubation resulting from direct pharyngeal trauma caused by the Magill forceps. In a previous study, ${ }^{2}$ there was a lower incidence of sore throat using a tube exchanger and vascular forceps $v s$ using a stylet. In this study, the incidence of sore throat tended to be lower in group $\mathrm{V}$ than in group $\mathrm{M}$, although the difference was not significant.

This study has several limitations. For instance, the participating anesthesiologists were not blinded to the assigned groups, and they were more familiar with using Magill forceps than they were with using vascular forceps. In addition, although we analyzed the incidence of epistaxis, we did not evaluate its severity. Finally, a larger sample size is needed to evaluate the incidence of sore throat with regard to different intubation techniques.

This study shows that total intubation time was significantly lower when using a GVL with a tube exchanger and vascular forceps (group V) vs when using a GVL with Magill forceps (group M). The incidence of epistaxis was also significantly lower in group $\mathrm{V}$ than in group M. Therefore, when a GVL is used, nasotracheal intubation with a tube exchanger and vascular forceps offers advantages over the Magill forceps.

Acknowledgements The authors sincerely thank the Hanyang University E-world Center for their considerable help in the preparation of the manuscript. 
Conflict of interest There is no external funding or competing interests to declare.

Editorial responsibility This submission was handled by Dr. Philip M. Jones, Associate Editor, Canadian Journal of Anesthesia.

Author contributions Jong H. Yeom, Woo J. Shin, Woo J. Jeon, and Sang $Y$. Cho were involved in the study design and manuscript writing. Dae W. Ahn was involved in the preoperative and postoperative visits. Mi K. Oh, Woo J. Jeon, and Sang Y. Cho were involved in the study implementation.

Open Access This article is distributed under the terms of the Creative Commons Attribution-NonCommercial 4.0 International License (http://creativecommons.org/licenses/by/4.0/), which permits any noncommercial use, distribution, and reproduction in any medium, provided you give appropriate credit to the original author(s) and the source, provide a link to the Creative Commons license, and indicate if changes were made.

\section{References}

1. Jones PM, Armstrong KP, Armstrong PM, et al. A comparison of GlideScope videolaryngoscopy to direct laryngoscopy for nasotracheal intubation. Anesth Analg 2008; 107: 144-8.

2. Jeon WJ, Shim JH, Cho SY, Baek SJ. Stylet- or forceps-guided tube exchanger to facilitate GlideScope intubation in simulated difficult intubations-a randomised controlled trial. Anaesthesia 2013; 68: 585-90.

3. Salibian H, Jain S, Gabriel D, Azocar RJ. Conversion of an oral to nasal orotracheal intubation using an endotracheal tube exchanger. Anesth Analg 2003; 95: 1822.

4. Nakata $Y$, Niimi $Y$. Oral-to-nasal endotracheal tube exchange in patients with bleeding esophageal varices. Anesthesiology 1995; 83: $1380-1$.

5. Niforopoulou P, Pantazopoulos I, Demestiha T, Koudouna E, Xanthos T. Video-laryngoscopes in adult airway management: a topical review of the literature. Acta Anaesthesiol Scand 2010; 54: 1050-61.

6. Liu EH, Goy $R W$, Tan BH, Asai T. Tracheal intubation with videolaryngoscopes in patients with cervical spine immobilization: a randomized trial of the AirwayScope and the GlideScope. Br J Anaesth 2009; 103: 446-51.

7. Lai HY, Chen IH, Chen A, Hwang FY, Lee Y. The use of the GlideScope for tracheal intubation in patients with ankylosing spondylitis. Br J Anaesth 2006; 97: 419-22.

8. Dupanovic M, Isaacson SA, Borovcanin Z, et al. Clinical comparison of two stylet angles for orotracheal intubation with the GlideScope video laryngoscope. J Clin Anesth 2010; 22: 352-9.

9. Moore MS, Wong AB. GlideScope intubation assisted by fiberoptic scope. Anesthesiology 2007; 106: 885.

10. Xue FS, Li CW, Zhang GH, et al. GlideScope-assisted awake intubation: initial experience in 13 patients. Anaesthesia 2006; 61: 1014-5

11. Shim JH, Jeon WJ, Cho SY, Choe GH. Comparison of the GlideScope and the McGrath method using vascular forceps and a tube exchanger in case of simulated difficult airway intubation. Korean J Anesthesiol 2016; 69: 133-7.

12. Hirabayashi $Y$. GlideScope videolaryngoscope facilitates nasotracheal intubation. Can J Anesth 2006; 53: 1163-4.

13. Xue F, Zhang G, Liu J, et al. A clinical assessment of the GlideScope videolaryngoscope in nasotracheal intubation with general anesthesia. J Clin Anesth 2006; 18: 611-5.

14. Kim YC, Lee SH, Noh GJ, et al. Thermosoftening treatment of the nasotracheal tube before intubation can reduce epistaxis and nasal damage. Anesth Analg 2000; 91: 698-701.

15. Lim CW, Min SW, Kim CS, Chung JE, Park JE, Hwang JY. The use of a nasogastric tube to facilitate nasotracheal intubation: a randomised trial. Anaesthesia 2014; 69: 591-7.

16. Seo KS, Kim JH, Yang SM, Kim HJ, Bahk JH, Yum KW. A new technique to reduce epistaxis and enhance navigability during nasotracheal intubation. Anesth Analg 2007; 105: 1420-4.

17. Enk D, Palmes AM, Van Aken H, Westphal $M$. Nasotracheal intubation: a simple and effective technique to reduce nasopharyngeal trauma and tube contamination. Anesth Analg 2002; 95: 1432-6. 